\title{
Perfusion defect size predicts engraftment but not early retention of intra-myocardially injected cardiosphere-derived cells after acute myocardial infarction
}

\author{
Riikka Lautamäki · John Terrovitis • \\ Michael Bonios • Jianhua Yu • Benjamin M. Tsui • \\ M. Roselle Abraham · Frank M. Bengel
}

Received: 14 March 2011/Revised: 13 May 2011/Accepted: 13 June 2011/Published online: 25 June 2011

(C) The Author(s) 2011. This article is published with open access at Springerlink.com

\begin{abstract}
Therapeutic cell retention and engraftment are critical for myocardial regeneration. Underlying mechanisms, including the role of tissue perfusion, are not well understood. In Wistar Kyoto rats, syngeneic cardiospherederived cells (CDCs) were injected intramyocardially, after experimental myocardial infarction. CDCs were labeled with $\left[{ }^{18} \mathrm{~F}\right]$-FDG $(n=7)$, for quantification of 1 -h retention, or with sodium-iodide-symporter gene (NIS; $n=8$ ), for detection of 24-h engraftment by reporter imaging. Perfusion was imaged simultaneously. Infarct size was $37 \pm 9$ and $38 \pm 9 \%$ of LV in FDG and NIS groups. Cell signal was located in the infarct border zone in all animals. No significant relationship was observed between infarct size and 1-h CDC retention $(r=-0.65 ; P=0.11)$. However, infarct size correlated significantly with 24 -h engraftment $(r=0.75 ; P=0.03)$. Residual perfusion at the injection site was not related to cell retention/engraftment. Larger infarcts are associated with improved CDC engraftment. This observation encourages further investigation of microenvironmental conditions after ischemic damage and their role in therapeutic cell survival.
\end{abstract}

R. Lautamäki · F. M. Bengel

Division of Nuclear Medicine, Department of Radiology,

Johns Hopkins Medical Institutions, Baltimore, MD, USA

J. Terrovitis - M. Bonios - M. R. Abraham

Division of Cardiology, Department of Medicine,

Johns Hopkins Medical Institutions, Baltimore, MD, USA

J. Yu · B. M. Tsui

Division of Medical Imaging Physics, Department of Radiology,

Johns Hopkins Medical Institutions, Baltimore, MD, USA

F. M. Bengel $(\bowtie)$

Department of Nuclear Medicine, Hannover Medical School,

Carl-Neuberg-Str. 1, 30625 Hannover, Germany

e-mail: bengel.frank@mh-hannover.de
Keywords Cardiosphere-derived cells . Myocardial regeneration - Myocardial perfusion . Cell tracking

\section{Introduction}

The clinical benefit of cardiac cell transplantation has been debated [19]. Several studies have observed that only a small fraction of transplanted cells survives in the injured heart $[10,23,27]$. Accordingly, strategies to optimize the therapeutic value of cell transplantation are being explored. Those include promoting cell proliferation and differentiation, and augmenting cell survival and engraftment $[23,28]$. There is increasing evidence that the tissue environment is a critical determinant of the fate of stem cells after delivery. Some signaling molecules, including inflammatory markers, adhesion molecules, and hypoxia markers are temporarily over-expressed after myocardial infarction and seem to be involved in therapeutic cell survival [6, 13]. It is hoped that an improved understanding of the interaction between host tissue and exogenous therapeutic cells can be used to improve the regenerative benefit of cell therapy.

Noninvasive molecular imaging can contribute in this regard. PET, SPECT and MRI techniques have been developed to follow the fate of cells [2, 3]. Additionally, these methods enable simultaneous characterization of the host tissue through interrogation of perfusion, viability or other molecular events. Integrated analysis of imaging signals may not only be helpful in defining the interaction between host tissue and cell survival. It may also help to establish a future use of tissue imaging to guide regenerative therapy with regards to the optimal time point, patient group and myocardial region for cell delivery. 
In this report, we present a first step towards integrated analysis of host tissue conditions and stem cell engraftment, by investigating the relationship between myocardial perfusion and the engraftment of an innovative therapeutic cell type, cardiosphere-derived cells (CDCs) [1, 14, 20, 24].

\section{Materials and methods}

\section{Cell preparation}

CDCs were cultured from tissue samples derived from explanted hearts from male Wistar Kyoto rats, as previously described [24]. Wistar Kyoto rats are inbred syngeneic animals and therefore appropriate for use in cell transplantation studies, without the need for immunosuppression. In brief, CDCs were prepared by cutting tissue samples into small pieces, digesting them with trypsin and culturing them on fibronectin-coated tissue culture dishes using complete explant media [24]. Fibroblast-like adherent cells and a smaller number of phase-bright cells migrate from the explants. The latter cells are collected by washing, then seeded in poly-D-lysine coated plates, using specific media as previously described [24]. Under these conditions, cells aggregate in cardiospheres, which are harvested, seeded in fibronectin-coated tissue culture flasks for expansion as monolayers and cultured in CEM. For in vivo injection, CDCs were resuspended in $120 \mu \mathrm{l}$ of PBS.

\section{Animal protocol}

Syngeneic Wistar Kyoto rats $(n=15)$ were utilized for all experiments. Myocardial infarction was induced by permanent ligation of the left anterior descending coronary artery, immediately followed by direct intramyocardial injection of CDCs, as described previously [26, 27]. For intramyocardial injection, the standard volume of $120 \mu \mathrm{lCDC}$ suspension was injected into two sites of the accessible anterior/anterolateral infarct border zone. Because of the relatively large volume, confluence of the injectate from both sites within tissue was regularly observed. The number of injected CDCs was 2 million in all cases of FDG-labeling. In the genetically labeled NIS group, 6 of 8 animals received the standard dose of 2 million CDCs. For reasons related to other study topics [26], one animal received only one million CDCs, and another animal received 3 million CDCs. The animal protocol was approved by the institutional animal care and use committee.

\section{Direct CDC labeling with $\left[{ }^{18} \mathrm{~F}\right] \mathrm{FDG}$, PET imaging} of immediate cell retention

For quantification of immediate cell retention at approximately $1 \mathrm{~h}$ after delivery, a previously validated approach was utilized in 7 rats [27]. In brief, CDCs were incubated with $\left[{ }^{18} \mathrm{~F}\right]-F D G$ ex vivo, at a nontoxic activity level. The syringe, containing no more than $37 \mathrm{kBq}(8-30 \mathrm{kBq})$ of $\left[{ }^{18} \mathrm{~F}\right]$-FDG-labeled CDCs, was imaged for $5 \mathrm{~min}$ in a $\mathrm{GE}$ eXplore VISTA small animal scanner (GE Healthcare, Waukesha, WI, USA), immediately prior to injection. Radiolabeled CDCs were then injected intramyocardially, and the empty syringe was imaged again to determine net injected activity. This was considered to be superior to dose calibrator measurements because the detection system was identical to in vivo measurements. Subsequently, the infarct animal was placed in the scanner and a 60 min scan of $\left[{ }^{18} \mathrm{~F}\right]-F D G-l a b e l e d ~ C D C$ biodistribution was obtained. After the completion of cell tracking, 37-55 MBq of ${ }^{13} \mathrm{NH}_{3}$ were injected intravenously via tail vein and a 20 min static image of myocardial perfusion was obtained. CT scans were obtained for attenuation correction. Using volume of interest (VOI) technique, absolute radioactivity in the myocardium was quantified. Early CDC retention was determined by the fraction of (CDC-derived) myocardial radioactivity, expressed as percent of injected radioactivity (i.e. injected number of cells).

This method has been validated against ex vivo polymerase chain reaction (PCR) previously [27]. In brief, CDCs from male donors were injected into the myocardium of 6 female recipients. Animals were sacrificed after $1 \mathrm{~h}$, hearts were excised, DNA was isolated and retained donor cell numbers were quantified by real-time PCR for the SRY gene located on the Y chromosome. After testing in triplicate, the amount of retained cells measured by this ex vivo technique was $18 \pm 12 \%$ of injected cells, which was identical to the results obtained by in vivo FDG imaging in an albeit separate group of animals [27] (measurements in the same group are impossible because of the expected rapid cell kinetics and because ex vivo and in vivo techniques cannot be applied simultaneously). Furthermore, the specificity of the FDG signal for living cells has been tested in our prior work. Intramyocardial injection of an FDG-containing cell lysate resulted in low retention of injected radioactivity, and ex vivo studies showed that FDG is stably retained by cells after labeling and thorough rinsing [27]. Thus, a significant contribution of nonspecific radioactivity to the FDG signal at the very early time of $1 \mathrm{~h}$ after injection of FDG-labeled cells is unlikely.

\section{Genetic CDC labeling with NIS, SPECT imaging} of 24-h cell engraftment

For measurement of cell engraftment after $24 \mathrm{~h}$, a previously validated reporter gene based approach was utilized in eight rats [26]. In brief, a lentiviral vector system was used to label CDCs, without effect on cell viability of function. Expression of the human sodium-iodide 
symporter (hNIS) gene was driven by constitutively active promoters, namely CAG (composite promoter consisting of the CMV enhancer and chicken beta actin promoter; $n=3$ ) in initial studies, and was later switched to cytomegalovirus promoter (CMV; $n=5$ ) due to limited expression under CAG. At $24 \mathrm{~h}$ after infarction and CDC injection, animals were imaged using a Gamma Medica X-SPECT-CT scanner (Gamma Medica, Northridge, California). The NIS reporter probe ${ }^{99 \mathrm{~m}} \mathrm{Tc}(285 \pm 63 \mathrm{MBq})$, and the perfusion tracer ${ }^{201} \mathrm{Tl}(37 \pm 11 \mathrm{MBq})$ were coinjected via the tail vein. Dual isotope SPECT was acquired $1 \mathrm{~h}$ after tracer injection. Using VOI technique, the ratio of ${ }^{99 \mathrm{~m}} \mathrm{Tc}$ activity at the cell injection site to bloodpool was measured as a semiquantitative parameter of the magnitude of cell engraftment [26]. VOIs were drawn around the maximum of radioactivity at the cell injection site, excluding areas of the surrounding normally perfused myocardium or the LV cavity. Background activity was measured in an area of the myocardium outside the VOI but within the perfusion deficit and subtracted from the VOI activity. A third VOI was then placed at a location inside the LV cavity, to obtain signal intensity in the blood pool. All VOI activities were corrected for attenuation by using $\mathrm{CT}$ density images. A contrast ratio $(\%)$ was then defined as $100 \times[$ [signal in the cells $)-$ (signal in blood pool)]/signal in blood pool. In order to correct for differences in promoter strength and injected cell number, the contrast ratio was then normalized to injected cell number and to the mean of each promoter group for subsequent comparison with perfusion. The resulting percentage of the group mean was taken as a semi-quantitative measure of relative cell engraftment after $24 \mathrm{~h}$.

Like the FDG-based approach, the NIS-labeling method has been previously compared to ex vivo PCR measurements of cell engraftment [26]. The same technique as described above (detection of SRY gene in hearts of female recipients receiving male donor cells) was used. Four rats were injected with NIS-labeled CDCs and sacrificed at days 1 and 8 . PCR confirmed a rapid cell loss, from $13 \pm 4 \%$ retention of injected cells on day 1 , down to $3 \pm 2 \%$ on day 8 . This matched a loss of the semiquantitative image signal that was found in parallel groups at serial SPECT imaging after NIS-labeled cell injection [26].

\section{Correction for contamination of perfusion images}

by cell-derived radioactivity

In dual isotope SPECT, downscatter of ${ }^{99 \mathrm{~m}} \mathrm{Tc}$-derived photons into the lower energy ${ }^{201} \mathrm{Tl}$ window may impair the accuracy of integrated analysis of perfusion and cell survival. Hence, correction was performed, based on phantom measurements. A list-mode SPECT scan for a
$\mathrm{Tc}^{99 \mathrm{~m}}$ filled small sphere, embedded in a water-filled ratsized cylinder, was acquired using the small animal scanner. Data were reconstructed using ${ }^{201} \mathrm{Tl}$ and ${ }^{99 \mathrm{~m}} \mathrm{Tc}$ energy windows, and the ratio of count intensities was determined. Downscatter from ${ }^{99 \mathrm{~m}} \mathrm{Tc}$ to ${ }^{201} \mathrm{Tl}$ windows was measured as $1.6 \%$. This factor was used for a pixelwise correction of ${ }^{201} \mathrm{Tl}$ perfusion images.

In serially acquired PET images, ${ }^{13} \mathrm{NH}_{3}$ perfusion studies were obtained after completion of imaging of $\left[{ }^{18} \mathrm{~F}\right]$ FDG-labeled CDCs. Because the injected dose of ${ }^{13} \mathrm{NH}_{3}$ was more than thousandfold higher than that of $\left[{ }^{18} \mathrm{~F}\right]$-FDGlabeled cells $(37-55 \mathrm{MBq}$ vs. $8-30 \mathrm{kBq})$, no spillover effects were expected and no correction was performed.

Polar map analysis of myocardial perfusion

${ }^{201} \mathrm{Tl}$ and ${ }^{13} \mathrm{NH}_{3}$ perfusion datasets were volumetrically sampled and polar maps of left ventricular myocardial activity were generated by previously validated software $[9,17]$. Static polar maps were normalized to their maximum and a threshold of $60 \%$ of the individual maximal uptake was used to define the perfusion defect. The perfusion defect size was quantified as the percentage of the entire polar map, and thus as the percentage of LV myocardium. The myocardial segments defined for perfusion maps were then transferred to identical locations in the coregistered cell tracking studies, and a polar map of the cell signal was obtained. Figure 1 highlights the process for creating polar maps from static tomographic images of perfusion and cell signal. The peak signal in cell maps was used to identify the injection site relative to the perfusion defect. Based on relative location of the cell signal to the defect area, the injection was determined as a border zone injection, if edges of both areas overlapped, as an infarct injection, if cell signal was completely surrounded by infarct area, or as a remote injection if cell signal was completely outside the infarct area. Additionally, a region of six segments around the peak cell signal was used to determine residual perfusion (as percent tracer uptake) at the cell injection site. Three animals (one in the FDG group and two in the NIS group) had to be excluded from the latter analysis due to spillover of extracardiac liver activity into the cell injection site on perfusion images.

Statistical analysis

Values are reported as mean \pm standard deviation (SD). Student's $t$ test was used to compare continuous variables between groups. Pearson's correlation coefficient, along with Fisher's r-to-z transformation was used to determine the relationship between variables. $P<0.05$ was chosen for statistical significance. 


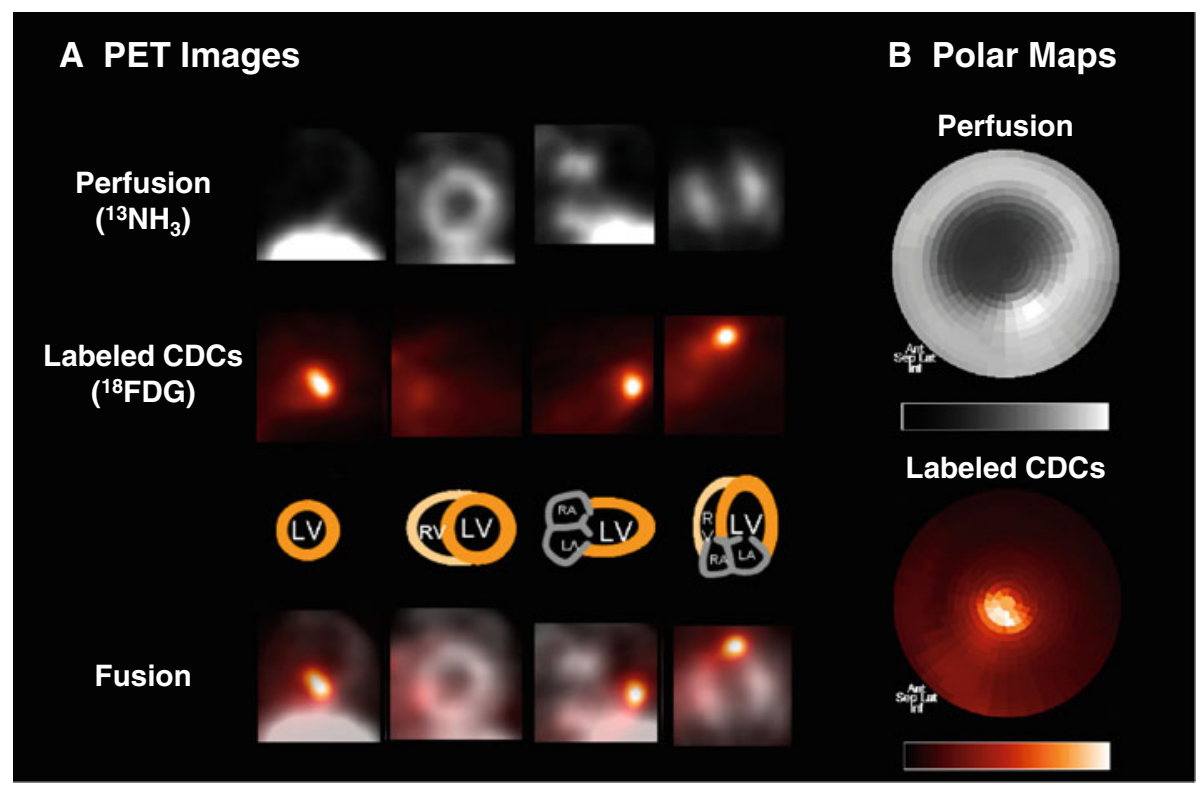

Fig. 1 Integration of cell tracking and myocardial perfusion imaging. a Reangulated tomographic PET images of myocardial perfusion $\left({ }^{13} \mathrm{NH}_{3}\right.$, grey scale $)$ and $\left[{ }^{18} \mathrm{~F}\right]-\mathrm{FDG}$-labeled cardiosphere-derived cells (CDCs; hot metal scale), $1 \mathrm{~h}$ after intramyocardial CDC injection in a rat model of acute myocardial infarction. Fusion images confirm CDC injection and retention in the hypoperfused apical infarct border zone.

\section{Results}

Similarity of study groups

The perfusion defect as a marker of infarct size was comparable between ${ }^{13} \mathrm{NH}_{3}$ PET studies of the early retention group and ${ }^{201} \mathrm{Tl}$ SPECT studies of the 24-h engraftment group $\left(37 \pm 9 \%\right.$, range $25-53 \%$, for ${ }^{13} \mathrm{NH}_{3}$; vs. $38 \pm 9 \%$, range $24-55 \%$, for ${ }^{201} \mathrm{Tl} ; P=\mathrm{NS}$ ), confirming comparability of methods and absence of modelrelated differences between groups.

\section{CDC signal}

In all animals of both groups, the cell signal was visually detectable and the location was in the infarct border zone in all cases (Figs. 2, 3). No injection into the infarct center or remote myocardium was detected by nuclear image analysis. Due to the limited spatial resolution of nuclear imaging techniques, the cell signal appeared as a single spot despite the use of two injection sites. Confluence of the injected volume from neighboring sites, and partial volume effects explain this observation. Residual perfusion at the cell injection site was $48 \pm 14 \%$ of $\mathrm{LV}$ maximum in the early retention group, and $57 \pm 9 \%$ in the 24-h engraftment group $(P=\mathrm{NS})$. Early retention of $\left[{ }^{18} \mathrm{~F}\right]-$ FDG-labeled CDCs in the respective group was $20 \pm 6 \%$ of injected cells. In absolute terms, this translates into a b Matching polar maps of perfusion and the $\left[{ }^{18} \mathrm{~F}\right]-\mathrm{FDG}-\mathrm{labeled} \mathrm{CDC}$ signal, created by use of identical search rays. Polar maps are a twodimensional displays of three-dimensional tracer distribution throughout the myocardium, showing anterior wall on top, inferior wall on bottom, septum on left, lateral wall on right, base in the periphery and apex in the center

retention of $400,000 \pm 12,000 \mathrm{CDCs}$ at the intramyocardial injection site, $1 \mathrm{~h}$ after injection of 2 Mio CDCs. For methodological reasons, 24-h engraftment was measured in relative terms and ranged from $45 \%$ below to $75 \%$ above group average.

Relationship between infarct characteristics and CDC signal

Residual perfusion at the injection site was not related to immediate cell retention $(r=-0.15 ; P=0.8)$ or $24-\mathrm{h}$ engraftment ( $r=0.12 ; P=0.8$ ). Additionally, no significant relationship was observed between infarct size and 1-h CDC retention, although there was a nonsignificant trend towards an inverse correlation $(r=-0.65 ; P=0.11)$. In the 24-h engraftment group, however, there was a significant positive correlation between the infarct size and the reporter probe signal from engrafted cells $(r=0.74$; $P=0.03$ ) (Fig. 4).

\section{Discussion}

In summary, noninvasive myocardial imaging was integrated with cell tracking in this project, in order to identify conditions of the host myocardium which are supportive of engraftment of therapeutic cells. Our results suggest that a larger perfusion defect after myocardial infarction is 


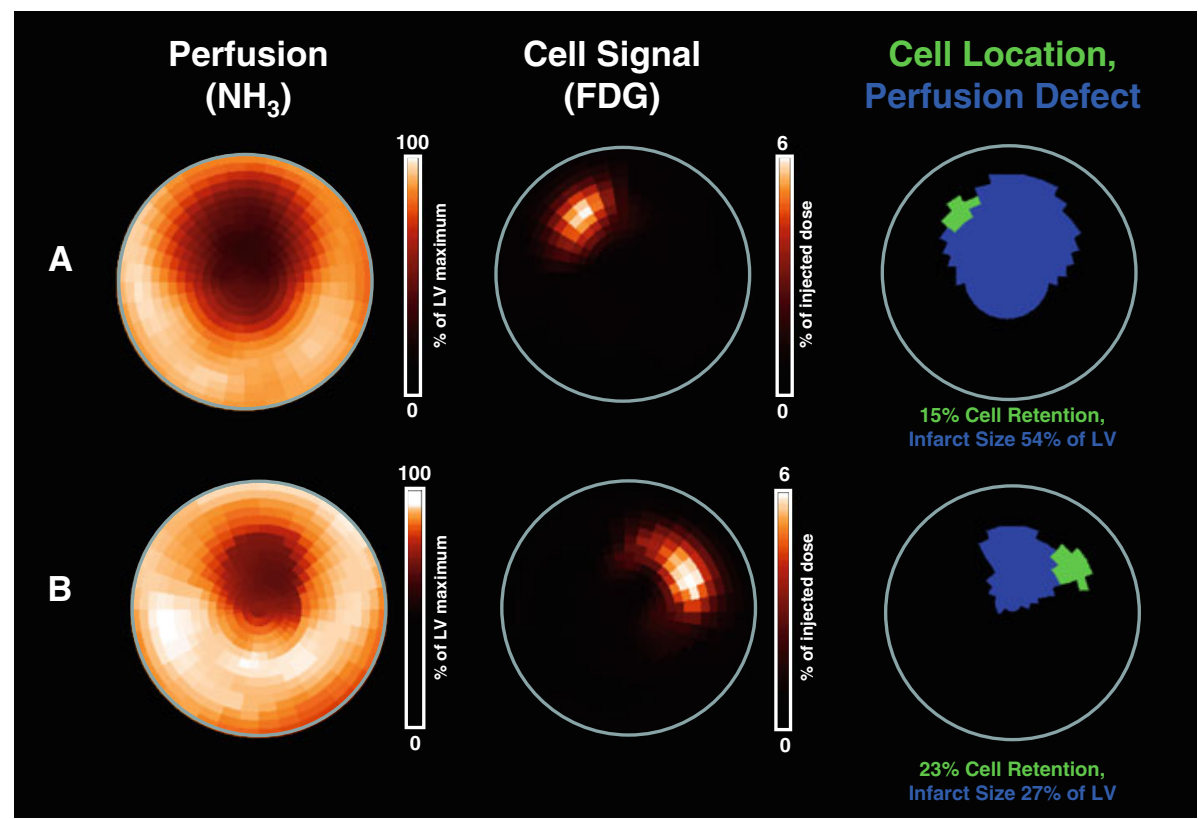

Fig. 2 Polar map analysis of perfusion defect and early retention of $\left[{ }^{18} \mathrm{~F}\right]-\mathrm{FDG}-\mathrm{labeled}$ cardiosphere-derived cells. Shown are polar maps of PET images in representative infarct animal with a large (a) and small (b) infarct. Polar maps of myocardial perfusion (left, measured by ${ }^{13} \mathrm{NH}_{3}$ ), the co-registered cell signal (middle), and of a result map showing the perfusion defect in blue and the cell location in green (right) are displayed. Note that the cell signal is located in the infarct border zone in both cases. Consistent with analysis of the entire group, quantitative cell signal strength is not significantly different between animals but tends to be lower in the larger infarct

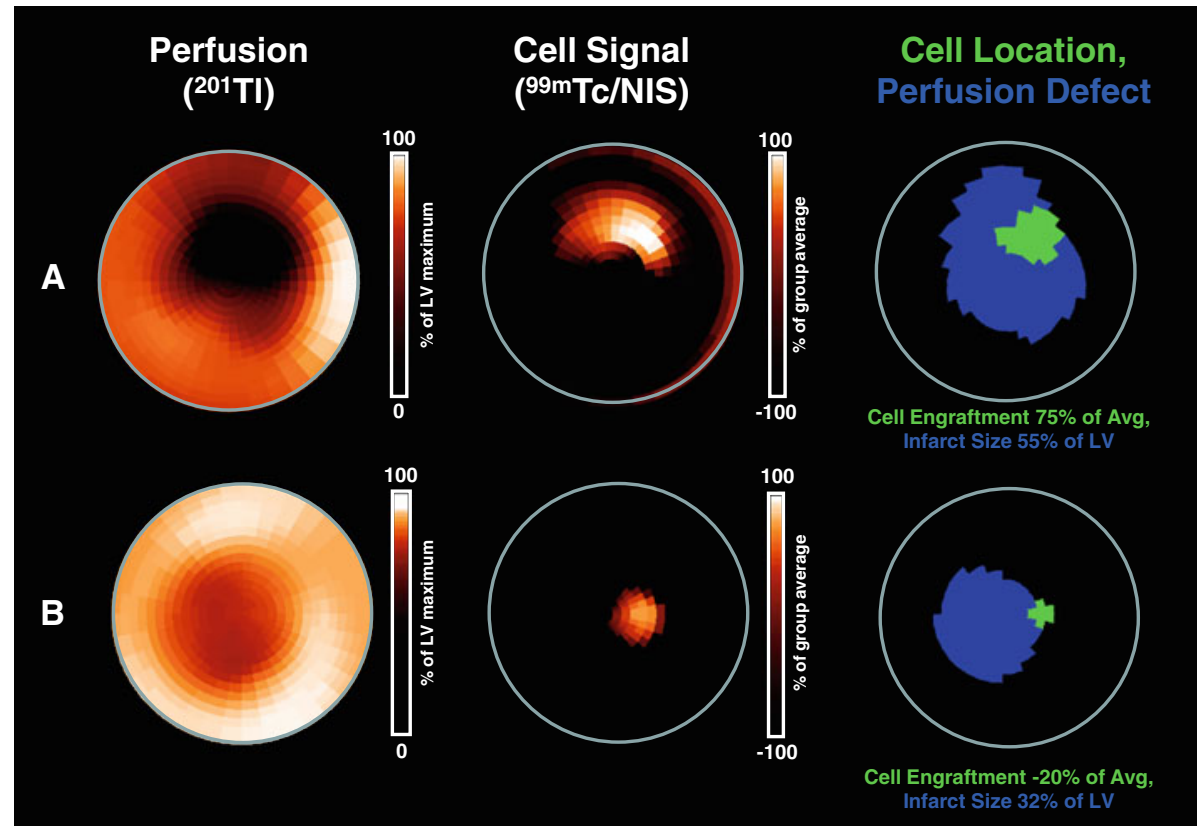

Fig. 3 Polar map analysis of perfusion defect and 24-h engraftment of NIS-labeled cardiosphere-derived cells. Shown are polar maps of SPECT images in representative infarct animal with a large (a) and small (b) infarct. Polar maps of myocardial perfusion (left, measured by ${ }^{201} \mathrm{Tl}$ ), the co-registered cell signal (middle, obtained by injection of the reporter probe ${ }^{99 \mathrm{~m}} \mathrm{Tc}$ ), and of a result map showing the

associated with a larger amount of CDC engraftment $24 \mathrm{~h}$ after intramyocardial injection into the infarct border zone. No significant relationship between perfusion defect size perfusion defect in blue and the cell location in green (right) are displayed. Note that the cell signal is located in the infarct border zone in both cases. Consistent with analysis of the entire group, and in contrast to early retention (Fig. 2), semiquantitative cell signal strength is higher in the larger infarct

and immediate cell retention at $1 \mathrm{~h}$ after injection was observed, although there was an opposite trend towards an inverse relationship. 
Fig. 4 Regression plots for perfusion parameters and cell survival. a Immediate retention of cells, measured by $\left[{ }^{18} \mathrm{~F}\right]-$ FDG-labeling, was not significantly correlated with infarct size, although there was a nonsignifcant trend towards inverse correlation. b 24-h engraftment of cells, measured by reporter gene imaging, showed a significant positive correlation with perfusion defect size. Cell engraftment was measured as relative signal intensity when compared to group average and normalized to cell number. $\mathbf{c}, \mathbf{d}$ Lack of significant correlation of early cell retention and 24-h engraftment with the residual perfusion at the cell injection site as a measure of injection location relative to infarct center. $I D$ injected dose, $L V$ left ventricle
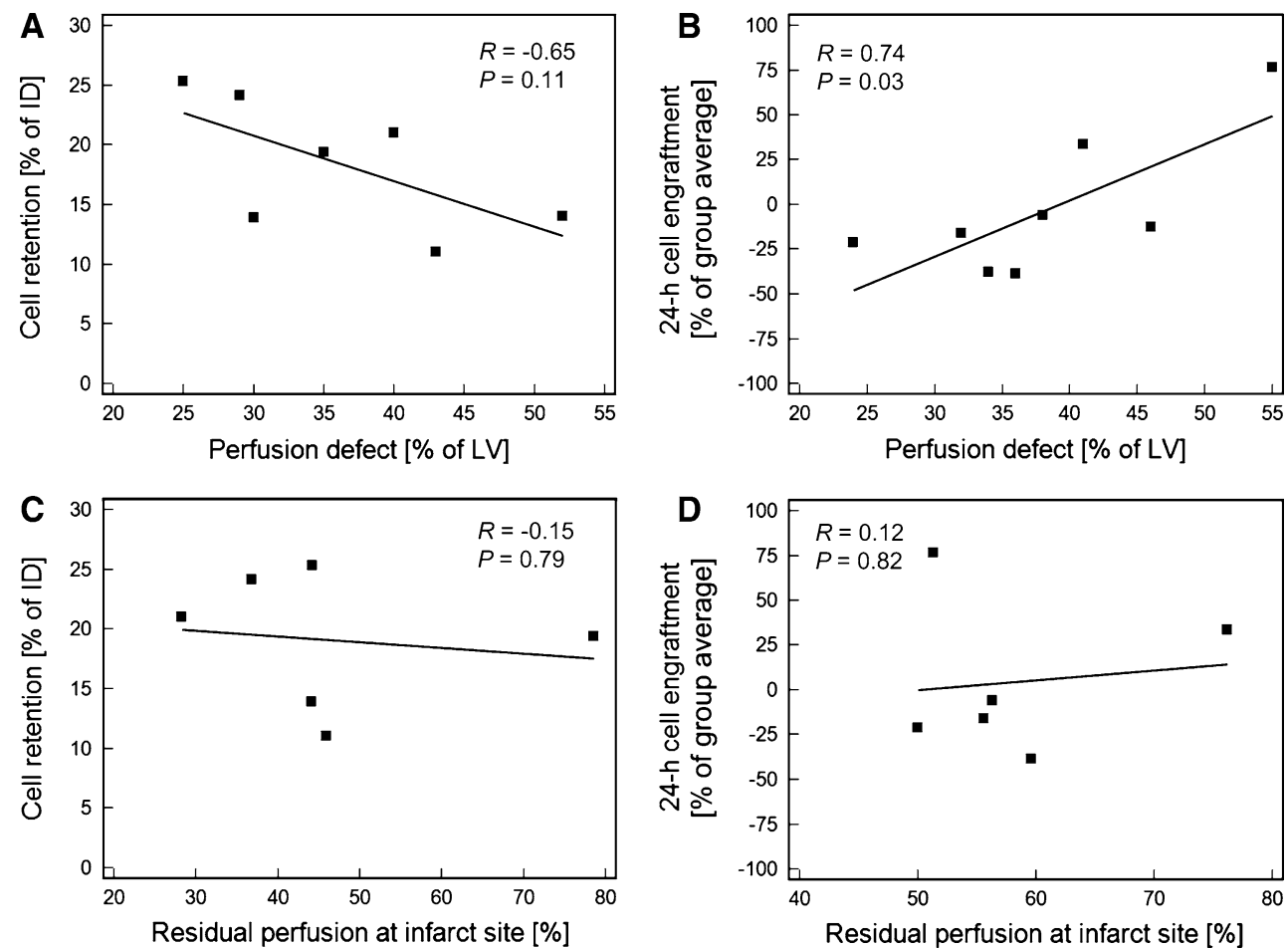

CDCs, which are found in adult myocardium, were used for cell delivery in this study. These cells can be isolated from myocardial biopsies and they can be expanded in vitro [24]. Their potential for myocardial regeneration has been demonstrated in mice, where CDCs improved left ventricular function after myocardial infarction [24], in rats after acute myocardial infarction [4], and in a porcine model of ischemic cardiomyopathy, where CDC injection resulted in a reduction of infarct size and reduced adverse remodeling [11]. Our prior experience has shown that CDCs can be efficiently labeled with $\left[{ }^{18} \mathrm{~F}\right]-\mathrm{FDG}$ and with reporter genes, for detection at different time points and under various conditions $[4,5,26,27]$. Our prior work in rats also showed that intravenously injected CDCs are mostly retained in lungs and that CDCs injected into the LV cavity after aortic clamping distribute diffusely in the entire myocardium [5]. Consequentially, because selective infusion into the infarct vessel (the most popular clinical technique) is not feasible in small animals, we chose intramyocardial injection as the best technique to target cells to the infarct border zone in our rat model. The setup used in this report has therefore been extensively validated. The novelty of the present study lies in its additional information about effects of the host tissue on CDC survival, derived from integrated noninvasive imaging.

Interestingly, immediate retention of CDCs after intramyocardial injection, as measured by direct labeling with $\left[{ }^{18} \mathrm{~F}\right]-\mathrm{FDG}$, was not significantly associated with any perfusion parameter. Visual analysis and quantitatively measured residual perfusion at the cell location confirm injection into the infarct border zone in our animals. The consistent location of injection, and the lack of correlation between residual perfusion and cell signal provide evidence against a confounding effect of the injection site in our results. Immediate retention may thus be determined mostly by mechanical factors such as myocardial contraction and injection technique. Consistently, a recent study showed that mechanical interventions such as sealing of the injection site with fibrin glue or global reduction of contractility by adenosine can be used during the intramyocardial injection to enhance early CDC retention [27].

In contrast to immediate retention, the $24 \mathrm{~h}$ engraftment of CDCs, as measured by the intensity of the NIS reporter gene signal, showed a significant, positive correlation with cell engraftment. This supports the notion that the myocardial host tissue environment influences the survival of transplanted cells, and it is consistent with a recent human study using $\left[{ }^{111} \mathrm{In}\right]$-labeled bone marrow cells, where the cell signal was inversely related with flow reserve and viability in the infarct area [21]. The perfusion defect size is a marker of the severity of ischemic damage to the myocardium. Ischemic damage triggers a variety of molecular mechanisms which may support the survival and engraftment of transplanted cells. Hypoxia induces expression of growth factors and adhesion molecules which regulate cell trafficking [6]. Additionally, ischemic damage triggers inflammation and extracellular matrix activation, which in turn support cell migration and angiogenesis [13]. 
Of note, many of these activated pathways can now be imaged noninvasively using molecular imaging techniques $[7,8,12,15,25]$. Future studies may thus focus on a direct, integrated assessment of the role of these molecular pathways, which are activated after myocardial infarction, on cell engraftment [18, 30]. Identification of a molecular signal from host myocardium which strongly predicts cell engraftment, may result in the future emergence of novel diagnostic algorithms which characterize the microenvironment to guide cell delivery with regards to suitable patients, optimal time point and optimal myocardial region. The present study should be seen as a first step into this direction.

Our work also has some clinical implications because it suggests that large infarcts are more likely to benefit from cell therapy. Notably, randomized studies using bonemarrow derived cells for treatment of acute myocardial infarction suggested that patients with larger infarcts and/or lower ejection fraction are more likely to benefit from cell therapy $[16,22,29]$. The current study does not only provide a rationale for subsequent studies looking into molecular events in the infarct area which may be specifically linked to cell engraftment. Measurements of infarct size may also be used for selection of subjects for cell therapy. Speculatively, an implementation of imaging to select candidates with large infarcts for cell therapy in future clinical trials may contribute to achieving better results and more homogeneous response.

There are some limitations of our work. First, it should be considered that we used two different groups of animals to analyze early retention and $24 \mathrm{~h}$ engraftment. The power of such a comparison is inferior to a serial analysis. However, imaging of $\left[{ }^{18} \mathrm{~F}\right]-\mathrm{FDG}$ labeled cells is restricted to the early phase after delivery, due to radioactive decay of the tracer. In addition, reporter gene imaging is not yet possible very early after cell delivery because cells are still in an energy-deprived state and will not yet show sufficient reporter gene activity. A combination of both techniques in the same cell/animals was considered too challenging for practical application. Importantly, both approaches of direct and genetic labeling have been compared against ex vivo PCR and yielded concordant results [26, 27]. Second, the genetically labeled group was somewhat inhomogeneous because different promoters and injected cell numbers were used. In order to overcome this heterogeneity, which was caused by other research aims that are not included in the present work, we normalized to cell number and group average. Correlation of NIS-derived cell engraftment with infarct size was nevertheless convincing, and in contrast to PET, which was employed for FDGlabeled cells, SPECT is not a truly quantitative technique in general.

\section{Conclusion}

A larger infarct results in a more suitable myocardial environment for engraftment of intramyocardially delivered cardiosphere-derived cells. This observation encourages further investigation of the effect of myocardial host tissue conditions on therapeutic cell survival.

Acknowledgments This study was supported by NIH grant 1RO1HL092985-01A2 (FMB and MRA). Dr. Lautamäki was supported by grants from The Finnish Cardiac Research Foundation, The Finnish Medical Foundation, The Instrumentarium Foundation for Science, and by a Bracco/SNM Research Fellowship in Cardiovascular Molecular Imaging.

Open Access This article is distributed under the terms of the Creative Commons Attribution Noncommercial License which permits any noncommercial use, distribution, and reproduction in any medium, provided the original author(s) and source are credited.

\section{References}

1. Altomare C, Barile L, Marangoni S, Rocchetti M, Alemanni M, Mostacciuolo G, Giacomello A, Messina E, Zaza A (2010) Caffeine-induced $\mathrm{Ca}(2+)$ signaling as an index of cardiac progenitor cells differentiation. Basic Res Cardiol 105:737-749. doi: 10.1007/s00395-010-0111-6

2. Beeres SL, Bengel FM, Bartunek J, Atsma DE, Hill JM, Vanderheyden M, Penicka M, Schalij MJ, Wijns W, Bax JJ (2007) Role of imaging in cardiac stem cell therapy. J Am Coll Cardiol 49:1137-1148. doi:10.1016/j.jacc.2006.10.072

3. Bengel FM, Schachinger V, Dimmeler S (2005) Cell-based therapies and imaging in cardiology. Eur J Nucl Med Mol Imaging 32 Suppl 2:S404-S416. doi:10.1007/s00259-005-1898-5

4. Bonios M, Chang CY, Pinheiro A, Dimaano VL, Higuchi T, Melexopoulou C, Bengel F, Terrovitis J, Abraham TP, Abraham MR (2011) Cardiac resynchronization by cardiosphere-derived stem cell transplantation in an experimental model of myocardial infarction. J Am Soc Echocardiogr (Epub ahead of print). doi: 10.1016/j.echo.2011.03.003

5. Bonios M, Terrovitis J, Chang CY, Engles JM, Higuchi T, Lautamaki R, Yu J, Fox J, Pomper M, Wahl RL, Tsui BM, O'Rourke B, Bengel FM, Marban E, Roselle Abraham M (2011) Myocardial substrate and route of administration determine acute cardiac retention and lung bio-distribution of cardiospherederived cells. J Nucl Cardiol 18:443-450. doi:10.1007/s12350011-9369-9

6. Ceradini DJ, Kulkarni AR, Callaghan MJ, Tepper OM, Bastidas N, Kleinman ME, Capla JM, Galiano RD, Levine JP, Gurtner GC (2004) Progenitor cell trafficking is regulated by hypoxic gradients through HIF-1 induction of SDF-1. Nat Med 10:858-864. doi: $10.1038 / \mathrm{nm} 1075$

7. Higuchi T, Bengel FM, Seidl S, Watzlowik P, Kessler H, Hegenloh R, Reder S, Nekolla SG, Wester HJ, Schwaiger M (2008) Assessment of alphavbeta3 integrin expression after myocardial infarction by positron emission tomography. Cardiovasc Res 78:395-403. doi:10.1093/cvr/cvn033

8. Higuchi T, Fukushima K, Xia J, Mathews WB, Lautamaki R, Bravo PE, Javadi MS, Dannals RF, Szabo Z, Bengel FM (2010) Radionuclide imaging of angiotensin II type 1 receptor 
upregulation after myocardial ischemia-reperfusion injury. J Nucl Med 51:1956-1961. doi:10.2967/jnumed.110.079855

9. Higuchi T, Nekolla SG, Jankaukas A, Weber AW, Huisman MC, Reder S, Ziegler SI, Schwaiger M, Bengel FM (2007) Characterization of normal and infarcted rat myocardium using a combination of small-animal PET and clinical MRI. J Nucl Med 48:288-294. doi:10.2967/jnumed.102.288294

10. Hofmann M, Wollert KC, Meyer GP, Menke A, Arseniev L, Hertenstein B, Ganser A, Knapp WH, Drexler H (2005) Monitoring of bone marrow cell homing into the infarcted human myocardium. Circulation 111:2198-2202. doi:10.1161/01.CIR.0000163546. 27639.AA

11. Johnston PV, Sasano T, Mills K, Evers R, Lee ST, Smith RR, Lardo AC, Lai S, Steenbergen C, Gerstenblith G, Lange R, Marban E (2009) Engraftment, differentiation, and functional benefits of autologous cardiosphere-derived cells in porcine ischemic cardiomyopathy. Circulation 120:1075-1083. doi: 10.1161/CIRCULATIONAHA.108.816058

12. Lautamaki R, Schuleri KH, Sasano T, Javadi MS, Youssef A, Merrill J, Nekolla SG, Abraham MR, Lardo AC, Bengel FM (2009) Integration of infarct size, tissue perfusion, and metabolism by hybrid cardiac positron emission tomography/computed tomography: evaluation in a porcine model of myocardial infarction. Circ Cardiovasc Imaging 2:299-305. doi:10.1161/ CIRCIMAGING.108.846253

13. Lu L, Zhang JQ, Ramires FJ, Sun Y (2004) Molecular and cellular events at the site of myocardial infarction: from the perspective of rebuilding myocardial tissue. Biochem Biophys Res Commun 320:907-913. doi:10.1016/j.bbrc.2004.06.034

14. Madonna R, Rokosh G, De Caterina R, Bolli R (2010) Hepatocyte growth factor/Met gene transfer in cardiac stem cellspotential for cardiac repair. Basic Res Cardiol 105:443-452. doi: 10.1007/s00395-010-0102-7

15. Meoli DF, Sadeghi MM, Krassilnikova S, Bourke BN, Giordano FJ, Dione DP, Su H, Edwards DS, Liu S, Harris TD, Madri JA, Zaret BL, Sinusas AJ (2004) Noninvasive imaging of myocardial angiogenesis following experimental myocardial infarction. J Clin Invest 113:1684-1691. doi:10.1172/JCI20352

16. Meyer GP, Wollert KC, Lotz J, Pirr J, Rager U, Lippolt P, Hahn A, Fichtner S, Schaefer A, Arseniev L, Ganser A, Drexler H (2009) Intracoronary bone marrow cell transfer after myocardial infarction: 5-year follow-up from the randomized-controlled BOOST trial. Eur Heart J 30:2978-2984. doi:10.1093/eurheartj/ehp374

17. Nekolla SG, Miethaner C, Nguyen N, Ziegler SI, Schwaiger M (1998) Reproducibility of polar map generation and assessment of defect severity and extent assessment in myocardial perfusion imaging using positron emission tomography. Eur J Nucl Med 25:1313-1321. doi:10.1007/s002590050301

18. Oerlemans MI, Goumans MJ, van Middelaar B, Clevers H, Doevendans PA, Sluijter JP (2010) Active Wnt signaling in response to cardiac injury. Basic Res Cardiol 105:631-641. doi: 10.1007/s00395-010-0100-9

19. Reffelmann T, Konemann S, Kloner RA (2009) Promise of bloodand bone marrow-derived stem cell transplantation for functional cardiac repair: putting it in perspective with existing therapy. J Am Coll Cardiol 53:305-308. doi:10.1016/j.jacc.2008.10.018

20. Sandstedt J, Jonsson M, Lindahl A, Jeppsson A, Asp J (2010) $\mathrm{C}$-kit+ CD45- cells found in the adult human heart represent a population of endothelial progenitor cells. Basic Res Cardiol 105:545-556. doi:10.1007/s00395-010-0088-1

21. Schachinger V, Aicher A, Dobert N, Rover R, Diener J, Fichtlscherer S, Assmus B, Seeger FH, Menzel C, Brenner W, Dimmeler S, Zeiher AM (2008) Pilot trial on determinants of progenitor cell recruitment to the infarcted human myocardium. Circulation 118:1425-1432. doi:10.1161/CIRCULATIONAHA.108.777102

22. Schachinger V, Erbs S, Elsasser A, Haberbosch W, Hambrecht R, Holschermann H, Yu J, Corti R, Mathey DG, Hamm CW, Suselbeck T, Assmus B, Tonn T, Dimmeler S, Zeiher AM (2006) Intracoronary bone marrow-derived progenitor cells in acute myocardial infarction. N Engl J Med 355:1210-1221. doi: 10.1056/NEJMoa060186

23. Seeger FH, Zeiher AM, Dimmeler S (2007) Cell-enhancement strategies for the treatment of ischemic heart disease. Nat Clin Pract Cardiovasc Med 4 Suppl 1:S110-S113. doi:10.1038/ncpcardio 0734

24. Smith RR, Barile L, Cho HC, Leppo MK, Hare JM, Messina E, Giacomello A, Abraham MR, Marban E (2007) Regenerative potential of cardiosphere-derived cells expanded from percutaneous endomyocardial biopsy specimens. Circulation 115:896908. doi:10.1161/CIRCULATIONAHA.106.655209

25. Su H, Spinale FG, Dobrucki LW, Song J, Hua J, Sweterlitsch S, Dione DP, Cavaliere P, Chow C, Bourke BN, Hu XY, Azure M, Yalamanchili P, Liu R, Cheesman EH, Robinson S, Edwards DS, Sinusas AJ (2005) Noninvasive targeted imaging of matrix metalloproteinase activation in a murine model of postinfarction remodeling. Circulation 112:3157-3167. doi:10.1161/ CIRCULATIONAHA.105.583021

26. Terrovitis J, Kwok KF, Lautamaki R, Engles JM, Barth AS, Kizana E, Miake J, Leppo MK, Fox J, Seidel J, Pomper M, Wahl RL, Tsui B, Bengel F, Marban E, Abraham MR (2008) Ectopic expression of the sodium-iodide symporter enables imaging of transplanted cardiac stem cells in vivo by single-photon emission computed tomography or positron emission tomography. J Am Coll Cardiol 52:1652-1660. doi:10.1016/j.jacc.2008.06.051

27. Terrovitis J, Lautamaki R, Bonios M, Fox J, Engles JM, Yu J, Leppo MK, Pomper MG, Wahl RL, Seidel J, Tsui BM, Bengel FM, Abraham MR, Marban E (2009) Noninvasive quantification and optimization of acute cell retention by in vivo positron emission tomography after intramyocardial cardiac-derived stem cell delivery. J Am Coll Cardiol 54:1619-1626. doi:10.1016/j.jacc. 2009.04.097

28. Wang QD, Sjoquist PO (2006) Myocardial regeneration with stem cells: pharmacological possibilities for efficacy enhancement. Pharmacol Res 53:331-340. doi:10.1016/j.phrs.2006.01.009

29. Wollert KC, Meyer GP, Lotz J, Ringes-Lichtenberg S, Lippolt P, Breidenbach C, Fichtner S, Korte T, Hornig B, Messinger D, Arseniev L, Hertenstein B, Ganser A, Drexler H (2004) Intracoronary autologous bone-marrow cell transfer after myocardial infarction: the BOOST randomised controlled clinical trial. Lancet 364:141-148. doi:10.1016/S0140-6736(04)16626-9

30. Wu J, Li J, Zhang N, Zhang C (2011) Stem cell-based therapies in ischemic heart diseases: a focus on aspects of microcirculation and inflammation. Basic Res Cardiol 106:317-324. doi: 10.1007/s00395-011-0168-X 